\title{
COMPARISON OF SOIL MOISTURE INDICES AND FIELD MEASUREMENTS IN HILLY AGRICULTURAL LANDS OF SW HUNGARY
}

\section{GÁBOR NAGY1*, DÉNES LÓCZY ${ }^{1}$, SZABOLCS CZIGÁNY ${ }^{1}$, MAURO HRVATIN ${ }^{2}$, ROK CIGLIČ ${ }^{2}$}

${ }^{1}$ Institute of Geography and Earth Sciences, University of Pécs, Pécs

${ }^{2}$ Anton Melik Geographical Institute, Research Centre of the Slovenian Academy of

Sciences and Arts, Ljubljana

*Email: gnagy@gamma.ttk.pte.hu

Received 14 March 2021, accepted in revised form 22 April 2021

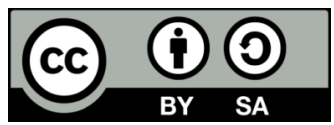

\begin{abstract}
The retention of surface runoff and the preservation of soil moisture are among the most important water-related ecosystem services. In addition to field monitoring, advanced remote sensing techniques have been devised to reveal soil moisture dynamics on agricultural land. In our study we compare two soil moisture indices, TWI and SAVI, in three agricultural areas with different land use types. The SAVI has been found suitable to point out spatial variation on the moisture conditions of the vadose zone.
\end{abstract}

Keywords: water stress, soil moisture dynamics, remote sensing, volumetric soil water content $(\theta v)$, tension, Topographic Wetness Index (TWI), Soil Adjusted Vegetation Index (SAVI)

\section{Introduction}

Soil moisture content is an environmental property which is highly appreciated under the conditions of global climate change. In the Carpathian Basin climate change will primarily involve marked aridification trends (Meyer et al. 2017). On agricultural land water availability, in close interaction with other properties like soil structure, aeration, nutrient supply, soil reaction and microbial activity, is vital for crop cultivation (Rodríguez-Ituber \& Poparto 2007, Várallyay 2015). In agriculture soil moisture can be preserved through optimized arable and grazing land management, minimal tillage or organic farming (Várallyay 2016; Eurlex Document 52017AE1814 2017). In the landscape, different combination of land uses result in different soil moisture, hydrology, and other characteristics (see Ciglič and Nagy 2019 for some examples). Land use also influence ecosystem services (Riberio, Šmid Hribar 2019). The spatial pattern of soil moisture content depends on the land use mosaic, the quality of land cover, topography (slope inclination and exposure), the severity of soil erosion, texture and hydraulic conductivity of soil (Várallyay 2003, Pásztor et al. 2016).

Several approaches have been proposed for the estimation of soil moisture dynamics (Rodríguez-Ituber \& Poparto 2007, Brocca el al. 2017). The common problem of field measurements, remote sensing detection and numerical modelling is the masking 
effect of vegetation and land use which reduces spatial variation. Analyzing NDVI values, Nicolai-Shaw et al. (2017) found that at the peak of drought spells great anomalies of precipitation, temperature and evapotranspiration are observed, while the vegetation index values often show considerable delays. This time lag is probably due to the lack of information on soil moisture in the deeper root zone which is not properly detected by remote sensing. Thus, the water available for plants is generally underestimated. Variation in grasslands is usually greater than for forests. This may be related to the capability of trees to access moisture at greater depths and to store water under dry conditions. Yang et al. (2015) studied seven hillslopes on the Longtan catchment (Henan province, China) and found a positive correlation between the Topographic Wetness Index (TWI) and nearsurface $(0-1 \mathrm{~m})$ soil moisture content and an inverse correlation with soil moisture at depths below $2 \mathrm{~m}$. In the deep layers biomass correlated negatively with soil moisture. Soil moisture stored in shallow horizons is obviously more dependent on topography. Gou et al. (2020) observed in the chernozem soils of Heilongjiang province of NE-China that land use type was more influential on soil moisture pattern in the deeper horizons than in the shallow horizons, while, in an opposite way, the impact of topography was less discernible in the deeper than in the surface horizons. Therefore, it is claimed that land use and topography jointly control soil moisture distribution at various depths.

The objective of our research was to compare the Soil Adjusted Vegetation Index (SAVI) and the Topographic Wetness Index (TWI) values with the measured soil moisture content change in three agricultural areas with different land use classes. This is a novel investigation in as much as no similar study has been made in the Transdanubian Hills.

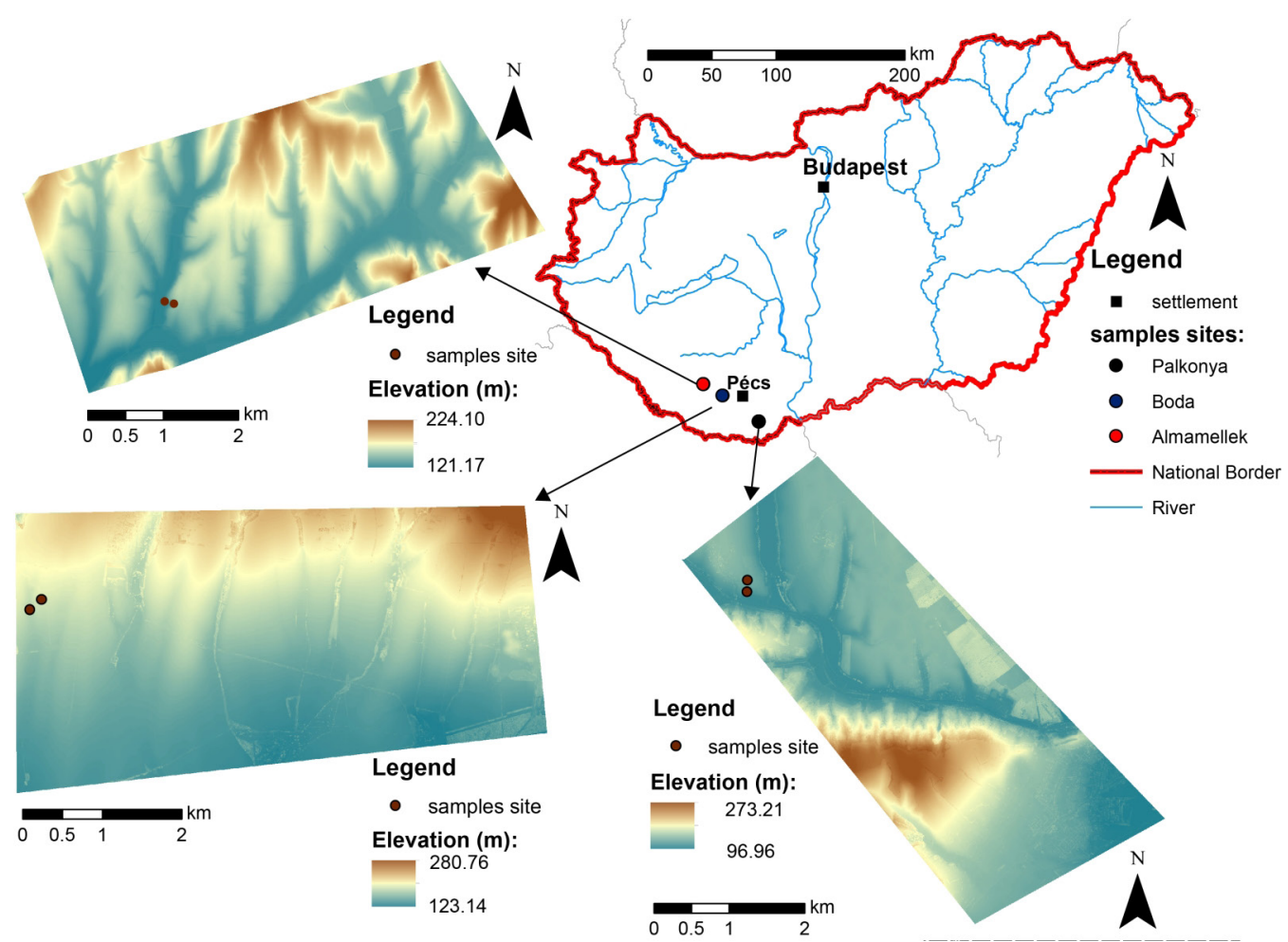

Fig. 1. Locations of study areas in SW Hungary 


\section{Methods}

\section{Location of study sites}

For the investigation three study areas had been selected in the Transdanubian Hills: at the villages of Boda, Palkonya and Almamellék (Fig. 1). It is a region of semihumid continental climate modified by the climatic type of the year (whether continental, Atlantic or Mediterranean) and the orographic effect. Although in most years precipitation shows an increasing gradient towards the west, in 2019, when field measurements were made, rainfall totals showed a rather mosaic pattern with annual precipitations of 630, 770 and $830 \mathrm{~mm}$ in Boda, Almamellék and Palkonya, respectively. In all study areas slightly eroded brown forest soils (e.g., WRB: Endocalcic Luvisol) with clay illuviation and formed on loess parent material are typical (Szalai 2008). Soil depth typically ranges from 70 $\mathrm{cm}$ to $250 \mathrm{~cm}$ (Hervai et al. 2017). Average slope angle for the Boda and Almamellék areas is $4.24 \%$, while for Palkonya it is $8.98 \%$. Although all of the areas are agricultural lands, land use is different: arable farming at Boda, cherry orchard at Palkonya and grazing land at Almamellék.

\section{Monitoring system}

To monitor moisture dynamics in the study areas over the growing season, at the top and bottom of slopes Teros 12 volumetric soil moisture sensors and Teros 21 tensiometers were placed at 10 and $30 \mathrm{~cm}$ depths in the topsoil. At the upper sites of measurement Decagon ECRN-100 tipping bucket rainfall gauges were installed to detect and quantify rainfall events.

\section{Calculating Topographic Wetness Index}

The Topographic Wetness Index (TWI) is used to estimate the distribution of moisture in an area based solely on topographic conditions (Beven \& Kirkby 1979). The TWI can be calculated from the Digital Elevation Model (DEM) using the following equation:

$$
\mathrm{TWI}=\ln (\mathrm{a} / \tan \beta) \quad \text { (eq. } 1)
$$

where a is upslope catchment area above the studied pixel $\left(\mathrm{m}^{2}\right), \beta$ is slope inclination in degrees. TWI is a dimensionless number, ranging from 0 to 30 . The SAGA GIS software was employed in its calculation.

\section{Remote sensing estimation of plant veg- etation index}

The various satellite systems scan the surface below with different number and width of bands. The detected signals inform about the state and changes (direction of ongoing processes) of the ground surface (Xue \& Su 2017; Ladányi \& Kovács 2010). The NDVI index relies on reflectance in the red (R) spectral band absorbed by chlorophyll molecules (at 580-680 nm wavelengths) and in the near infrared (NIR) band, where reflectance by plant cell structures is strong (at 725-1100 nm wavelengths) (Tucker 1979; Jackson et al. 1983; Justice et al. 1984). The NDVI is calculated from the following equation:

$$
N D V I=\frac{N I R-R}{N I R+R}
$$

where $\mathrm{R}$ is the spectral reflectance of red visible light, NIR is the spectral reflectance of near infrared radiation. NDVI is dimensionless and ranges from -1.0 to +1.0 . Typically, vegetation shows values between 0.1 and 0.7 , the higher index values indicating higher photosynthetic activity and healthier plants.

The Soil Adjusted Vegetation Index (SAVI) is a modified version of the NDVI, which also accounts for the deviations deriving from soil brightness and colour (Huete 1989).

$$
\text { SAVI }=\frac{(N I R-R)(1+L)}{(N R+R+L)}
$$

The value of $\mathrm{L}$ ranges from 0 to 1 . In practice the value of $\mathrm{L}$ is adjusted to environmental conditions. If vegetation cover is dense, it is close to 1 , which shows that the soil background does not affect the photosynthetic activity of the vegetation. 
However, this ideal situation rather rarely occurs in natural environment. Therefore, the SAVI index can only be applied if the foliage and vegetation cover are high (Major et al. 1990, Kaufman \& Tanré 1992). Under most climatic and pedologic conditions the value of $\mathrm{L}$ is around 0.5 : in this case the value of SAVI is close to 0 and is equal to the value of the NDVI (eq. 3 reduces to eq. 2). In general, however, an inverse relationship exists between the SAVI and the NDVI. Similarly, in most cases, the value of $\mathrm{L}$ is inversely proportional with the amount of vegetation to optimally adjust the soil influence.

For our investigation we used open-access ESA Sentinel-2 images with less than 10\% cloud cover for the period between March 1, 2019 and June 31, 2020. The SAVI index was calculated using ArcGIS 10.4. software.

\section{Statistical analysis}

Results were evaluated through Spearman rank correlation:

$$
r_{s}=1-\frac{\sum d_{i}^{2}}{n \cdot\left(n^{2}-1\right)}
$$

where $\mathrm{n}$ is the number of observed cases, $\mathrm{d}$ is the difference between two ranks of observations. Correlation values are between -1 and 1, showing the intensity of the relationship between the two variables. Correlations between measured soil moisture content, tension and SAVI index values were analysed for the period from March 1, 2019 to May 31, 2020.

\section{Results}

The data from our monitoring system for the study period show that the measurement sites at the top slopes were wetter in all the three areas (Nagy et al. 2020). This finding contradicts the prediction from TWI, i.e. that soil moisture is higher at the base of slope. The TWI distribution indicates that the position of landscape elements on the slope influences moisture dynamics downslope (Fig. 2).

The analysis of SAVI values showed, independent of study period, that at Palkonya and Boda the top measurement sites had at least by 0.042 higher soil moisture than the bottom ones (Fig. 2). While at Almamellék the top site had a higher SAVI value in spring, in summer the bottom site had a higher SAVI index.

On the arable land of Boda the measured soil moisture showed a negative correlation

Table 1. Correlation between measured volumetric water contents $\left(\theta_{v}\right)$ and matric potential $\left(\Psi_{m}\right)$ and the SAVI at the Boda study site

\begin{tabular}{cccccccccc}
\hline & \multicolumn{4}{c}{ Top monitoring site } & \multicolumn{3}{c}{ Bottom monitoring site } \\
\cline { 2 - 10 } & \multicolumn{2}{c}{$10 \mathrm{~cm}$} & \multicolumn{2}{c}{$30 \mathrm{~cm}$} & \multicolumn{2}{c}{$10 \mathrm{~cm}$} & \multicolumn{2}{c}{$30 \mathrm{~cm}$} \\
\cline { 2 - 9 } & $\theta_{v}$ & $\Psi_{m}$ & $\theta_{v}$ & $\Psi_{m}$ & $\theta_{v}$ & $\Psi_{m}$ & $\theta_{v}$ & $\Psi_{m}$ \\
\hline 2019 & $\mathbf{- 0 . 7 5 0}$ & -0.571 & -0.677 & -0.563 & $\mathbf{- 0 . 9 4 2}$ & -0.778 & -0.697 & -0.061 \\
$2019-2020^{*}$ & -0.087 & $\mathbf{0 . 1 2 7}$ & 0.088 & 0.077 & 0.281 & 0.656 & $\mathbf{0 . 8 1 6}$ & 0.720 \\
\hline *predicted & & & & & & & &
\end{tabular}

Table 2. Correlation between measured volumetric water contents $\left(\theta_{v}\right)$ and matric potential $\left(\Psi_{\mathrm{m}}\right)$ and the SAVI at Palkonya study site

\begin{tabular}{cccccccccc}
\hline & \multicolumn{4}{c}{ Top monitoring site } & \multicolumn{3}{c}{ Bottom monitoring site } \\
\cline { 2 - 10 } & \multicolumn{2}{c}{$10 \mathrm{~cm}$} & \multicolumn{2}{c}{$30 \mathrm{~cm}$} & \multicolumn{2}{c}{$10 \mathrm{~cm}$} & \multicolumn{2}{c}{$30 \mathrm{~cm}$} \\
\cline { 2 - 9 } & $\theta_{v}$ & $\Psi_{m}$ & $\theta_{v}$ & $\Psi_{m}$ & $\theta_{v}$ & $\Psi_{m}$ & $\theta_{v}$ & $\Psi_{m}$ \\
2019 & $\mathbf{0 . 5 9 7}$ & 0.259 & 0.696 & 0.525 & $\mathbf{0 . 5 1 3}$ & 0.201 & 0.486 & 0.417 \\
$2019-2020$ & -0.574 & $\mathbf{- 0 . 4 7 2}$ & -0.579 & -0.318 & -0.679 & -0.317 & $\mathbf{- 0 . 6 3 2}$ & -0.306 \\
\hline
\end{tabular}


(a)

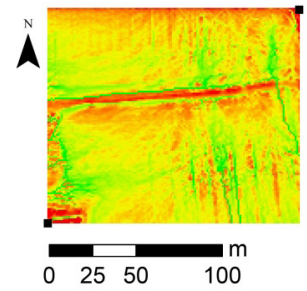

(c)

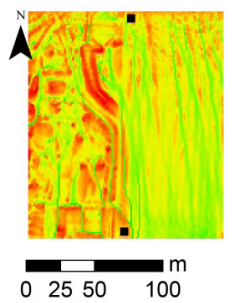

(e)

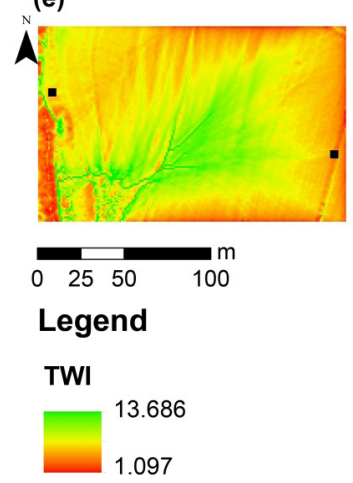

(b)
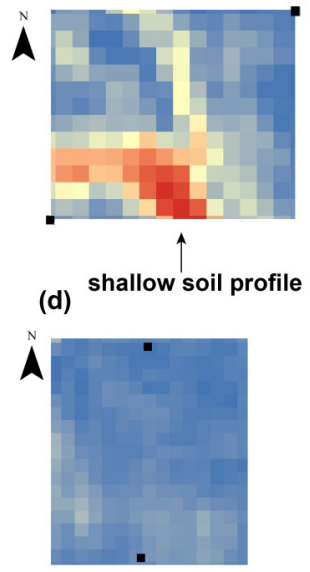

(f)

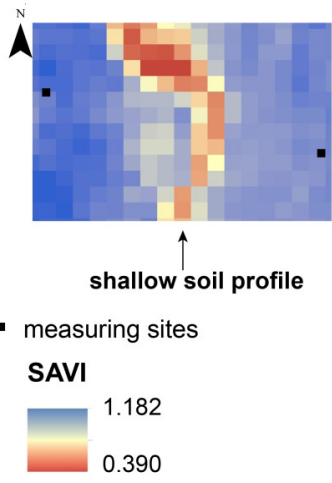

Fig. 2. TWI and SAVI indexes at the study sites. (a), TWI of Boda; (b) SAVI of Boda; (c), TWI of Palkonya; (d), SAVI of Palkonya; (e), TWI of Almamellék; (f), SAVI of Almamellék

with SAVI at both soil depths and for both positions of measurement sites in 2019. The correlation between volumetric water content $\left(\theta_{\mathrm{v}}\right)$ and SAVI was $r=-0.697$ for 2019 . There is an inverse relationship between the two variables (Table 1 ), while tension was not linked to SAVI ( $\mathrm{r}=-0.061$ at slope bottom and at $30 \mathrm{~cm}$ ). Over the 2019-2020 measurement period there was strong correlation at the bottom site at $30 \mathrm{~cm}$ depth.

While the correlations between SAVI and $\theta_{v}$ and between SAVI and tension are positive for Palkonya and for 2019, for the entire study period in 2019-2020 it is negative (Table 2). The strongest correlation was found between $\theta_{\mathrm{v}}$ and SAVI at $30 \mathrm{~cm}$ depth $(\mathrm{r}=0.696)$, while the weakest between tension and SAVI at the bottom site at $10 \mathrm{~cm}$ depth $(\mathrm{r}=0.201)$ for 2019. Regarding the whole period, the strongest correlation was found between $\theta_{\mathrm{v}}$ and tension at the slope bottom site and at 10 $\mathrm{cm}$ depth $(\mathrm{r}=-0.679)$ and the weakest also at the bottom site at $30 \mathrm{~cm}(\mathrm{r}=-0.306)$.

For the grazing land site of Almamellék no period with unambiguous positive correlation could be identified (Table 3). In the 2019 period at $30 \mathrm{~cm}$ depth of the upper measurement site a strong negative correlation was observed between SAVI and $\theta_{\mathrm{v}}(\mathrm{r}=-0.899)$ and a medium strong correlation at $30 \mathrm{~cm}$ depth of the lower measurement site between tension and SAVI $(\mathrm{r}=0.729$ ). In the entire 2019-2020 period there was a very weak correlation between 
Table 3. Correlation between measured volumetric water contents $\left(\theta_{\mathrm{v}}\right)$ and matric potential $\left(\Psi_{\mathrm{m}}\right)$ and the SAVI at the Almamellék study site

\begin{tabular}{cccccccccc}
\hline & \multicolumn{4}{c}{ Top monitoring site } & \multicolumn{3}{c}{ Bottom monitoring site } \\
\cline { 2 - 10 } & \multicolumn{2}{c}{$10 \mathrm{~cm}$} & \multicolumn{2}{c}{$30 \mathrm{~cm}$} & \multicolumn{2}{c}{$10 \mathrm{~cm}$} & \multicolumn{2}{c}{$30 \mathrm{~cm}$} \\
\cline { 2 - 10 } & $\theta_{v}$ & $\Psi_{m}$ & $\theta_{v}$ & $\Psi_{m}$ & $\theta_{v}$ & $\Psi_{m}$ & $\theta_{v}$ & $\Psi_{m}$ \\
\hline 2019 & $\mathbf{- 0 . 4 5 2}$ & -0.329 & -0.899 & -0.881 & $\mathbf{0 . 4 6 7}$ & 0.651 & 0.628 & 0.729 \\
$2019-2020$ & 0.181 & $\mathbf{- 0 . 0 2 5}$ & 0.291 & 0.125 & 0.136 & 0.174 & $\mathbf{0 . 3 2 1}$ & 0.149 \\
\hline
\end{tabular}

SAVI and $\theta_{v}$ for both measurement sites at 30 cm soil depth $(r>0.290)$.

The correlations with SAVI were the strongest where the rhizosphere was more developed, like in the case of the cherry orchard in Palkonya. The SAVI best correlated with $\theta_{\mathrm{v}}$ at all three study sites.

When the phenological stages are considered, in spring, and especially in March, the soil is wet, but it is not reflected in the vegetation as it is not yet developed. April was (and is usually) particularly dry period of the year, hence soil moisture negatively correlated with the SAVI. In summer the deeper root zone was wet and the vegetation was green, but at a depth of $30 \mathrm{~cm}$ the correlation with the SAVI was positive.

\section{Discussion and conclusions}

Our results support the view that vegetation and land use have a masking effect (Rodríguez-Ituber \& Poparto 2007; Brocca et al. 2017) and apparently moderate differences in the actual distribution of soil moisture, particularly in the case of the SAVI for the Palkonya orchard. However, this observation is contradicted by findings in the arable and grassland areas, where the influence of shallow soil and outcropping loess is manifested in SAVI values (Fig. 2). This points to the origin of the masking effect in root development: the deeper roots find available water, the least it is reflected in SAVI values. This assumption supports the experience by Nicolai-Shaw et al. (2017) that the changes are often reflected in the vegetation indices with delay. They also warn that remotely sensed root-zone moisture data are specific to plants. Partly in accordance, and partly opposed to Yang et al. (2015), we found positive correlation between the SAVI and the actual moisture contents at a depth of $10 \mathrm{~cm}$, but inverse correlation at a depth of $30 \mathrm{~cm}$.

According to Yang et al. (2015) the TWI positively correlated with near-surface soil moisture content (at $0-1 \mathrm{~m}$ ). Our results only revealed positive correlation between TWI and $\theta_{v}$ for the depth of $30 \mathrm{~cm}$. This can probably be explained with the water retention capacity of anthropogenic landscape microelements (hedgerows, tree rows) and the infiltration induced by such elements (Syrbe - Grunewald 2017). Our results are in harmony with the claim by Guo et al. (2020) that land use class has a greater impact on the deeper root zone than on the surface layer. In areas where the vegetation had deeper reaching roots, we found higher SAVI values (above 1.102). Their other assumption that the impact of topography on the deeper layer was weaker than on the surface layer could also be confirmed. This phenomenon was particularly conspicuous where the soil was shallower and the SAVI value was less than 0.405 .

According to our results the following conclusions have been drawn:

i. Temporarily a relationship between SAVI and soil moisture content can be observed and their correlation depends on the period of observation (the actual weather conditions of the growing season and the phenological phase).

ii. The SAVI is suitable to point out spatial variation of moisture conditions of the vadose zone. It is also capable to supply data 
for precision farming algorithms on moisture dynamics, moisture conservation and water supplying capacities of the individual agricultural fields provided the same crop is grown on them in subsequent seasons.

\section{Acknowledgements}

Authors are grateful for the financial support from the National Research, Development and Innovation Office (NKFIH) within the framework of the Hungarian-Slovenian collaborative project "Possible ecological control of flood hazard in the hill regions of Hungary and Slovenia" (contract no SNN 125727) and within the framework of the programme Excellence in Higher Education, Theme II. 3. ("Innovation for sustainable life and environment"). The authors acknowledge the study was performed in the frame of a project Possible ecological control of flood hazard in the hilly regions of Hungary and Slovenia (ARRS, N6-0070) and a research programme Geography of Slovenia (ARRS, P6-0101). The project and the programme were financially supported by the Slovenian Research Agency.

\section{References}

Brocca, L. - Ciabatta, L. - Massari, C. - Camici, S. - Tarpanelli, A. (2017): Soil Moisture for Hydrological Applications: Open Questions and New Opportunities. Water, 9, 2, 140-160. Doi:10.3390/w9020140

Ciglič, R. - Nagy, G. (2019): Naturalness level of land use in a hilly region in north-eastern Slovenia. Geografski vestnik, 91, 1, 9-31. Doi:10.3986/ GV91101

Guo, X. - Fu, Q. - Hang, Y. - Lu, H. - Gao, F.- Si, J. (2020): Spatial Variability of Soil Moisture in Relation to Land Use Types and Topographic Features on Hillslopes in the Black Soil (Mollisols) Area of Northeast China. Sustainability, 12, 9, 35523573. Doi: $10.3390 /$ su 12093552

Hervai, A. - Pirkhoffer, E. - Fábián, Sz. Á.- Halmai, Á.- Nagy, G. - Lóczy , D. - Czigány, S. (2017): Interpolation and $3 \mathrm{D}$ visualization of soil moisture. Landscape \& Environment, 11, 1, 23-34. Doi: $10.21120 / \mathrm{LE} / 11 / 1 / 3$

Huete, A.R. (1988): A Soil-adjusted Vegetation Index (SAVI). Remote Sensing of Environment, $25, \quad 3, \quad 295-309$. Doi: 10.1016/00344257(88)90106-X

Jackson, R.D. - Slater, P.N. - Pinter, P.J. (1983):
Discrimination of growth and water stress in wheat by various vegetation indices through clear and turbid atmospheres. Remote Sensing of the Environment, 15, 187-208.

Justice, C.O. - Townshend, J.R.G. - Holben, B.N. Tucker, C.J. (1985): Analysis of the phenology of global vegetation using meteorological satellite data. International Journal of Remote Sensing, 6, 8, 1271-1318. Doi: 10.1080/01431168508948281

Kaufman, Y.J. - Tanré, D. (1992): Atmospherically resistant vegetation index (ARVI) for EOSMODIS. IEEE Transactions on Geoscience and Remote Sensing, 30, 261-270. Doi: $10.1109 / 36.134076$

Ladányi, Zs. - Kovács, F. (2010): Spektrális indexek szerepe a tájváltozás, táji érzékenység megfigyelésében. In: Szilassi P. - Henits L. (szerk.): Tájváltozás értékelési módszerei a XXI. században. JATE Press, Szeged. 203-214. (Földrajzi tanulmányok 5) (in Hungarian)

Major, D.J. - Baret, F. - Guyot, G. (1990): A ratio vegetation index adjusted for soil brightness. International Journal of Remote Sensing, 11, 5, 727-740. Doi: 10.1080/01431169008955053

Meyer, B.C. - Mezősi, G. - Kovács, F. (2017): Landscape degradation at different spatial scales caused by aridification. Moravian Geographical Reports, 25, 4, 11-21. Doi: 10.1515/mgr2017-0023

Nicolai-Shaw, N. - Zscheischler, J. - Hirschi, M. Gudmundsson, L. - Seneviratne, S. I. (2017): A drought event composite analysis using satellite remote-sensing based soil moisture. Remote Sensing of Environment, 203, 216225. Doi:10.1016/j.rse.2017.06.014

Nagy, G. - Lóczy, D. - Czigány, Sz. - Pirkhoffer, E. Fábián, Sz.Á. - Ciglič, R. - Ferk, M. (2020): Soil moisture retention on slopes under different agricultural land uses in hilly regions of Southern Transdanubia. Hungarian Geographical Bulletin 68, 2, Doi: 10.15201/ hungeobull.69.3.3

Pásztor, L. - Laborczi , A. - Takács, K. - Szatmári, G. - Illés, G. - Fodor, N. - Négyesi, G. -Bakacsi, Z. - Szabó, J. (2016): Spatial distribution of selected soil features in Hajdú-Bihar county represented by digital soil maps. Landscape \& Environment, 10, 3-4, 203-213. Doi: 10.21120/LE/10/3-4/14

Ribeiro, D. - Šmid Hribar, M. (2019): Assessment of land-use changes and their impacts on ecosystem services in two Slovenian rural landscapes. Acta geographica Slovenica 59, 2, 143-159. Doi:10.3986/AGS.6636 
Rodríguez-Iturbe, I. - Porporato, A. (2007): Ecohydrology of Water-Controlled Ecosystems: Soil Moisture and PlantDynamics. Cambridge University Press: Cambridge, UK, pp. 460.

Syrbe, R.-U. - Grunewald, K. (2017): Ecosystem service supply and demand - the challenge to balance spatial mismatches. International Journal of Biodiversity Science, Ecosystem Services \& Management, 13, 2, 148-161. Doi: $10.1080 / 21513732.2017 .1407362$

Szalai, Z. (2008): Spatial and temporal pattern of soil $\mathrm{pH}$ and Eh and their impact on solute iron content in a wetland (Transdanubia, Hungary). Landscape \& Environment, 2, 1, 34-45. Retrieved from https://ojs.lib.unideb. hu/landsenv/article/view/2220

Tucker, C.J. 1979. Red and photographic infrared linear combinations for monitoring vegetation. Remote Sensing of the Environment, 8, 127150.
Xue, J. - Su, B. (2017): Significant Remote Sensing Vegetation Indices: A Review of Developments and Applications. Journal of Sensors, 2017, 1-17. Doi:10.1155/2017/1353691

Yang, L. - Chen, L. - Wei, W. (2015): Effects of vegetation restoration on the spatial distribution of soil moisture at the hillslope scale in semi-arid regions. CATENA, 124, 138146. Doi:10.1016/j.catena.2014.09.014

Várallyay, Gy. (2003): A talajok környezeti érzékenységének értékelése. Tájökológiai Lapok 1 (1): 45-62. (in Hungarian)

Várallyay, Gy. (2015): Soils as the Most Important Natural Resources in Hungary (Potentialities and Constraints). A Review. Agrokémia és Talajtan. 64, 2, 321-338. Doi: 10.1556/0088.2015.64.2.2 (in Hungarian)

Várallyay, Gy. (2016): A talaj multifunkcionalitása és korlátozó tényezői. Magyar Tudomány 177, 10, 1162-1174. (in Hungarian) 